\title{
WITNESSING, GRIEVING, AND REMEMBERING: LETTERS OF RESISTANCE, LOVE, AND RECLAMATION FROM DAUGHTERS OF IZZAT
}

\section{Mandeep Kaur Mucina}

\begin{abstract}
This article challenges public and private constructions of honourrelated violence as they impact second-generation South Asian women and girls in Canada. While much has been written about the victims of honour killings, including high profile cases of young women killed by their families in Canada, considerably less attention and space has been given to second-generation South Asian Canadian women and girl's stories of survivance and resistance against honour-based violence (HBV). This paper moves towards storying processes of grieving and of witnessing public stories of $\mathrm{HBV}$, and documents a collective writing process I undertook in collaboration with survivors of HBV. We shared narratives of grief and pain, and the power of collective storywork. The paper includes two letters that speak to the context in which second-generation South Asian women are embodying resistance and reclamation, and witnessing stories of grief, loss, love, and acceptance.
\end{abstract}

Keywords: honour based violence; witnesse; survivance; action based research;

Mandeep Kaur Mucina PhD is an Assistant Professor in the School of Child and Youth Care, University of Victoria, 3800 Finnerty Road, Victoria, BC V8W 2Y2. Email: mmucina@uvic.ca 
In 2009, I embarked on a research journey to understand how second-generation South Asian Canadian ${ }^{1}$ women were resisting acts of family violence in their lives. My reentry to graduate school was inspired by therapeutic work I had been doing as a counsellor in a diverse Toronto neighbourhood, where I was providing support to immigrant women and girls living with or leaving violent relationships. The families I worked with were fractured by their migration to this settler colonial nation, which had often resulted in mental health challenges and violence directed at women and girls in the family. On December 10, 2007, the murder of a young South Asian girl, Aqsa Parvez, by her father and brother reverberated through the South Asian communities across Toronto, including the community I was working in. Aqsa's story and body became symbols of a newfound public interest in honour killings, and what was often termed as a culture clash between the barbaric east and the liberal west (Abu-Lughod, 2002). I witnessed the women, girls, and families in this community express shame, guilt, and fear as they processed what had happened to Aqsa. I was particularly concerned for those "second generation"2 women and girls who were struggling with conflict in their families and navigating the racism and Islamophobia in the public sphere, and were now hearing the dominant narrative that Aqsa was murdered in a clash over the hijab.

Aqsa Parvez's death and the wider public response to her murder added fuel to my existing rage against the dominant racist discourses I had heard throughout my life. I was tired of hearing that South Asian women and girls were liable to experience violence from their fathers, brothers, and husbands, and that the men in our community were "barbaric" tribal patriarchs while the women needed to be saved by Western liberal feminism. The multiple conflicting messages left me rocking between rage and anxiety, as I was also moving through my own experience of exile from my family and community for transgressing perceived boundaries of izzat (Mucina, 2015). "Izzat" is a Punjabi word that can be translated as "honour", though that is an unsatisfyingly simple and limiting definition of what is historically a relevant cultural construct that shapes the actions of individuals and their responsibilities to family and community (Mucina, 2018). Izzat is

\footnotetext{
${ }^{1}$ In the Western context, the term "South Asian" encompasses people from at least seven countries with diverse languages, histories, and religions, and includes those with Bangladeshi, Bengali, East Indian, Goan, Gujarati, Hindu, Ismaili, Kashmiri, Nepali, Pakistani, Punjabi, Sikh, Sinhalese, Sri Lankan, and Tamil ancestry. My doctoral research (Mucina, 2015) focused specifically on Punjabi-speaking women living in Canada who identified as part of the South Asian Canadian community. I will be referring to the women in that study as Punjabi women. When referring to the wider community, I will use the term "South Asian Canadian community" to emphasize that the people who encompass the above diversity of language and religion all have their roots in the Indian subcontinent.

2"Second generation" describes "children of immigrants, those who were born and/or arrived in Canada before adolescence" (Rajiva, 2005, p. 25). Statistics Canada (2011) refers to generation status according to "the number of generations a person's ancestors have lived in Canada" (p. 3), specifically referring to the second generation as individuals born in Canada with at least one parent born outside Canada.

${ }^{3}$ For other meanings of this complex word, see https://www.shabdkosh.com/dictionary/punjabienglish/ rwer 1 rwer-meaning-in-english
} 
a system of thinking about and relating to oneself, one's family, and one's community that shapes how Punjabis see each other and engage with each other (Mucina, 2015, 2018).

I have lived with izzat as a second-generation Punjabi woman throughout my life, feeling and witnessing how perceived boundaries set around a woman's body in the name of izzat or honour can lead to violence. I could see my story reflected back each time a South Asian woman or girl was murdered and the words "honour killing" shaped the media stories, using her death as a way to fuel xenophobia and racism against communities of colour and culture. Feeling the need for alternative perspectives, I wanted to hear and learn from other South Asian women about their stories of survivance and resistance against violence, sexism, and racism throughout their lives, while also creating space to hear their stories of exile from family and community after behaviour perceived as transgressing the boundaries of izzat. Anishinaabe writer and distinguished scholar Gerald Vizenor (2013) defined survivance as "an intergenerational connection to an individual and collective sense of presence and resistance in personal experience and the world, or language, made particularly through stories" (p. 8). Vizenor saw resistance in stories and in transforming language; similarly, I am drawn to witnessing the power and resistance in how we story our lives.

Is it possible to centre stories of survivance and resistance while also calling out and denying the systems that focus on victimhood and cultural racism when talking about honour-based violence (HBV)? How do we resist "damage centered" research (Tuck, 2009, p. 415) while also giving space for the complex stories second-generation South Asian Canadian women have of living and navigating honour throughout their lives?

Over the course of 10 years, I have dedicated my research and practice to critically countering the discourses shaping mainstream ideas of South Asian Canadian women and girls and HBV. My work in the gender-based violence sector has concentrated on shaping critical understandings of violence in diasporic South Asian communities by focusing on acts of witnessing and stories of resistance and survivance, while paying attention to how women are reclaiming culture and identity for themselves. I was able to do this with the generosity and guidance of six secondgeneration Punjabi women who shared their life histories with me - each woman had experienced exile or lived in conflict with her family and community because her family perceived her as transgressing izzat (Mucina, 2015, 2018).

This paper ${ }^{4}$ moves towards storying a process of grieving, and witnessing public stories of $\mathrm{HBV}$, as well as undertaking a collective writing process with survivors of $\mathrm{HBV}$, sharing narratives of grief and pain and thus the power of collective storywork. The approach involved writing letters of grief, loss, love, and acceptance, both personal and collective.

\footnotetext{
${ }^{4}$ This paper emerges from two arts-informed parts of my doctoral research (Mucina, 2015), expanding slightly from the other articles in this special issue where authors have focused on challenging current structural systems and public discourses when talking about gender-based violence and HBV in South Asian communities.
} 
In the first part of the discussion below, I focus on witnessing - remembering the women who were murdered by their families, with izzat playing a significant role in justifying the violence. At significant moments during my own journey of addressing and fighting HBV, the honour-related murders of Amandeep Atwal; Jassi Sidhu; Aqsa Parvez; Zainab, Sahar, and Geeti Shafia; and Rona Muhammad Omar haunted and preoccupied me. I start this special issue by carving space to engage in an active written forum for witnessing their lives and reimagining their resistance against the dominant narratives that surround their deaths. I write a letter to them and in so doing ask the reader to bear witness to their lives, and to be mindful of the women and girls who are surviving every day within the confines of gender-based violence.

In the second half of the paper, I share a collective letter-writing process with the women who participated in my doctoral research. This collective writing draws from an action-based research approach, in which I invited women to participate in a process of engagement and creation that allowed us to speak to our collective experience with HBV and call out to our families, our communities, and the wider public. Action-based research pushes for participant or community involvement in the research process from the beginning to the end, focusing on collective action (Brydon-Miller et al., 2003; Pain, 2004, van der Muelen, 2011). In order to create individual and community capacity for resistance to violence, I lean towards promoting social justice action through research processes (Holder, 2015). What emerged from this gathering is an open letter addressed to our families and communities, a letter intended to raise critical consciousness in the South Asian Canadian community, as well as in White settler heteronormative society that orients towards patriarchal White supremacy to maintain a dominant narrative about HBV. This collective letter pushes the reader to question how we engage with violence in our communities and aims to instil in readers the importance of listening to intergenerational women's voices and stories of everyday survival against racism, colonialism, and heteropatriarchy.

\section{Reclaiming Izzat and Our Voices}

This special issue attempts to move away from self-serving discourses about HBV and challenge the cultural racism permeating these discourses while asking researchers, practitioners, and educators to consider how we conduct complex conversations about gender-based violence with children, youth, families, and communities. Often when I talk about my research within my own communities - including the Punjabi, Sikh, and wider South Asian Canadian communities - I get responses such as, "Honour-based violence does not happen in Canada" and "This happens among the lower classes in India." The intersection of class, caste, and patriarchy shape public and private responses within the South Asian communities in the West (Walton-Roberts \& Pratt, 2006). The HBV women and girls experience in their families as the families attempt to preserve honour and avoid shame is a form of gender-based violence and in my experience is an ongoing concern for South Asian women in Canada (Mucina, 2018). When we deny these concerns within our communities, it contributes to the cycles of family violence we continue to hear about in media discourses. Furthermore, Western media and Canadian policies continue to use second-generation South Asian Canadian women's bodies as a way to uplift Western feminism and the superiority of 
the West over the East, leaving families, women, and girls afraid of stigma and thus further silenced from sharing their first-person experiences (Razack, 2003).

In the West, a common threat to immigrant families is the erasure of who they were before migrating to the West and potential assimilation into the host culture (Rajiva, 2010). Resisting this requires careful negotiation on the part of parents regarding how culture, language, and religion are passed down and sustained in the second generation (An-Na'im, 2000; Espiritu, 2001; Haque, 2010). Competing with the pull from families to stay close to tradition is the push from the dominant society, whose agendas, stemming from multiculturalism, accommodation, and assimilation policies, are aimed at the second generation, also known as the "home grown generation" (Haque, 2010, p. 80), who are seen as the last hope for full assimilation into "Canadian values". This push and pull for the second generation and the migrant family often leads to what Abdullah An-Na'im (2000) refers to as fear responses and a sense that cultural survival is threatened, leading immigrant families to "turn inward and reinforc[e] the very practices that those on the outside are seeking to change" (p. 2).

Feelings of rage and urgency to say something ignited my writing and led me to pursue doctoral research on honour-based violence. This urgency was also the impetus for the initial meeting of a diverse group of South Asian Canadian women who joined forces to start this special issue. We originally came together to share in our common pain and to tell the multiple stories of honour we do not hear, yet have experienced, while dismantling the ideologies framing HBV and patriarchy. This urgency led me to pursue research on HBV, research that placed me as an outsider in my own community as I used a public platform to talk about stigmatized issues that plague the South Asian Canadian community, and to frame the stereotypes that follow us in the West. Yet, these feelings also come from a need or desire to witness those lives lost because of the violence of izzat. The complicated process of sharing narratives of women who are not here to share their own stories also leaves me with a sense of discomfort - one stemming from the fear, stigma, and shame of speaking about the violence that is connected to our cultures and religions, knowing such narratives can be taken up to ignite Orientalist discourses that support the White saviour complex. As HBV has gained currency in mainstream and academic discourses, acts of witnessing and listening to the stories of women who have experienced HBV remain few and far between. However, there is a penetrating gaze on honour killing. For example, Wikipedia pages are dedicated to Jassi Sidhu ${ }^{5}$, Aqsa Parvez ${ }^{6}$, and the Shafia family murders ${ }^{7}$, and documentaries and reenactments have aired on Canadian TV that engage with many of these women's lives and the stories leading up to their gruesome deaths (see CBC Fifth Estate, 2012, 2019; Saywell, 2010; Tripp, 2013).

Those who tell the stories of women killed in the name of honour are often outsiders who tell a story imposed on her corpse with little or no consent from her family. Their clear avoidance or

${ }^{5}$ https://en.wikipedia.org/w/index.php?title=Jaswinder_Kaur_Sidhu\&oldid=992601882

${ }^{6}$ https://en.wikipedia.org/w/index.php?title=Murder_of_Aqsa_Parvez\&oldid=984095005

${ }^{7}$ https://en.wikipedia.org/w/index.php?title=Shafia_family_murders\&oldid=1002676142 
assumption of the truth of a woman's story is a final act of violence on her body. In the case of the Shafia sisters, their daily struggles in the public realm and how they feared their family did not become public knowledge until journalists interviewed social workers and school professionals, whose comments revealed their complacency and their lack of capacity to respond appropriately to the girls' disclosures, so that only a bare minimum of action was taken ("Suicidal' Shafia daughter", 2011). The obsession on the part of the media to understand the short lives of the Shafia girls revealed these deeper systemic barriers, yet the narratives that often accompany this investigative journalism fail to name the complacency as a form of cultural racism, glossing over these important points as just bad practice on the part of professionals. As with any form of oppression, there is always resistance and struggle on the part of the oppressed (Freire, 1973), yet these discourses portray South Asian Canadian women as having no agency and as bodies "fixed in the Western imagination as confined, mutilated, and sometimes murdered in the name of culture" (Razack, 2004, p. 130.)

How dominant media discourses frame these murders is another kind of violence, one that leaves a stain on the South Asian diaspora. Reporting on honour killings sustains a narrative that South Asian Canadian women are victims of their barbaric cultures, supporting racist discourses about racialized immigrants who refuse to assimilate to settler colonial Canada and its values. Media's oppressive and obsessive gaze towards the gruesome has only led to defensiveness on the part of our community, rather than the collective action against HBV that will be necessary for any restoration and healing (Herman, 1992). What if we were to bear witness to the pain and violence in the South Asian Canadian community in order to instigate change and shift the ideologies underlying izzat and family violence?

The act of witnessing, as articulated by Dori Laub (1995), is about a "narrative that could not be articulated to be told, to be transmitted, to be heard" (p. 69). The act of witnessing includes both the survivor sharing and witnessing their own story, and a public listening. The power of witnessing, in the words of Bonnie Burstow (2003), should include "actions that counter alienation":

... Possible examples include telling one's story; naming one's own experiences; debunking myths about one's community; creating public rituals and ceremonies for expressing grief and outrage; rebuilding community ties, traditions, and models; reclaiming personal community or national space; reclaiming the product of one's labor; reconnecting with nature; and indeed all environmentally responsible liberatory initiatives. (p. 1313)

The power of witnessing cannot be denied. In trauma-informed work and in the gender-based violence field, it can accelerate the recovery, not only of individuals who are surviving the traumatic experience, but also of a community connected to the story. Paul Farmer (2003) outlined the critical role bearing witness plays in the social justice work of shifting and changing the world's inequities. The first step in bearing witness is to observe, document, and speak out about the 
suffering of others we have witnessed with our own eyes. By doing this, we are making connections between our personal pain and structural violence. Indeed, this special issue is a way of speaking to the structural violence of HBV and patriarchy. The authors of this special issue have made connections between the personal and political in multiple contexts, and ultimately they are speaking to how these systems impact children, youth, families, and communities.

The second step to bearing witness, Farmer (2003) wrote, is to stay present and engage with "surface silence" - a silence that is fostered by structurally inequitable and oppressive institutions - and to respect the "profound eloquence" that lies beneath it (p. 26). What power lies beneath the silence after a tragic death or loss in a community? Our desire as a society to label and engage with the stories of the dead fills a void for survivors where we try to give meaning to a violent moment difficult to comprehend. What would it look like to bear witness to the lives of women killed in the name of izzat?

It was important for me in my research journey to bear witness to the lives of women and girls who have become symbols of honour killing discourses in the West, and to weep and grieve through my writing. The following letter is one way of remembering Amandeep Atwal; Jassi Sidhu; Aqsa Parvez; Zainab, Sahar, and Geeti Shafia; and Rona Muhammad Omar, and of imagining their resistance, while offering space for multiple stories to emerge about women who have been killed in the name of izzat.

\section{A Letter of Resistance}

To my dear sisters, we have never met in person but your names have visited me at very important times in my life. I write this letter knowing we will never share eye contact as I read it, but I hope you hear the words as they fill space between us. I want to start by telling you all a story.

When I was 7 years old, my family decided to travel to India for the first time since they migrated to Canada 10 years prior. This trip was very exciting for me. As a child, I felt in my bones I was going somewhere special. I did not have the language or understanding of how this trip would influence the rest of my life, but it did in so many ways.

One of the many experiences I had that has always stayed with me, was witnessing a mourning ceremony in a rural village of northern India. We had been travelling all day to journey to my father's extended family's village, involving a bus ride and a long hike in the mountains of Himachal Pradesh. Once we arrived, there were only a few homes settled around the hills. Approaching the compound of the house, I heard distinct haunting sounds coming from a distant room on the compound where the family lived. It was the sound of women wailing. As we came closer, the wailing grew louder. I remember being afraid, not familiar with what my senses were experiencing. A sense of sorrow and pain was conjured deep inside me by hearing those voices. I also knew not to ask questions and to continue walking in silence. My mother, Bebe (grandmother), Phua-ji (paternal aunts) and Maawsi-ji (maternal aunt) all joined the women in the room. As they 
opened the door to enter, I peeked in to see what was happening, I saw a circle of women with their dupattas covering their eyes, swaying back and forth. I waited outside with my father and uncles. No men or children were permitted inside. The wailing carried on for an hour and then just like that, it all stopped. They were finished. Tears were wiped away and tea was served. There was no sign of what had just happened on any of the women's faces.

This mourning ceremony was for the death of a relative that had happened many months prior, but because my family had come to their home for the first time since then, it was necessary to do this public and very physical ritual. The wailing of the women was so visceral that even at such a young age, I felt the emotions that accompany a death, yet I do not even remember who had died and how I was connected to them. This ritual is one of the many ways my family remembers and mourns those we have lost, a ritual involving the physical and emotional connection to a community and to your self. Even if you do not participate in the wailing, hearing it is enough to feel something for the lost person or any person we have lost. Now, when I look back on it, I can see this ritual as a form of witnessing a person's life and death and giving those who have been left behind a chance to recognize their loss. To shower the body with tears of love, pain, and grief so they know we loved them. Many deaths have happened in my family and community since I witnessed my first wailing ceremony, and each time there is a comfort accompanying these emotions. I felt proud knowing the women in my family and community were the ones to lead this ceremony; its sacredness was held in a circle of women.

As I conjure these memories of family and friends who have died around me, I yearn to know more about you. I feel an overwhelming sense of sorrow if there was no wailing ceremony for you ... or maybe there was, but in the collective consciousness I remember seeing shame/regret/anger/resentment on the faces of my family and community when your death was shared. The public mourning seemed to have been stifled by the media headlines and overshadowed by the criminal acts of those who were connected to you by blood: your father, brothers, uncles, and mothers. I think about the love you felt by those who cared for each of you and want to embrace them in the public pain they suffered when each of you left this world.

Jassi Sidhu, I remember hearing about your body found in a ditch in India by the local authorities, but I do not recall my community, your community, our community wailing for your life lost so young. The anger inside me grew when they blamed you for your death.

Amandeep Atwal, I was in my car when I heard about your father stabbing you over and over again in your car. I do not remember anyone expressing grief for what happened to you, only shame. The rage inside me sprouted and grew when your story hit the news.

Aqsa Parvez, did you hear the wails of your sisters and brothers when we heard you had succumbed to your injuries in your hospital room? These wails were subdued by the noise of the media who wanted so desperately to hold you up as the poster child for honour killings. Aqsa, there is a picture of your mother in our local papers wailing - alone - without the 
accompaniment of her sisters. This must have hurt you as much as it pained me to witness. The fury inside started to trickle out and my voice quavered when I spoke about you in public.

Zainab, Sahar, Geeti, and Rona, I want to imagine you all holding hands together as you were plunged into the canals of Kingston. I heard your names repeated in every corner of Toronto, yet your names mean so much more than girls on a freedom pursuit, dying for "honour." My rage moved from silence to a storm of resistance and I will no longer remain quiet.

Jassi Sidhu, Amandeep Atwal, Aqsa Parvez, Zainab Shafia, Sahar Shafia, Geeti Shafia, Rona Muhammad Omar, I imagine, and hear, you struggled in many internal and external battles, many of which involved your responsibility to your family's izzat, and others involving your fight with patriarchy, racism, and sexism. I am sorry your bodies have become a site for discourses/words that burden you, even in death. I wail for you all through this letter and think about the sisters who have shared their stories of surviving izzat violence with me; we see you and ourselves in your stories. I hope this wailing can release the penetrating gaze and noise, which continues to follow your bodies, even in our memories of you. I wail for the short lives you lived, and we will remember each of you as resisters who chose to express your agency, not as women who were victims of tragic death. No, you are not victims, martyrs, or even statistics. You are our sisters, and we see your death as a reminder to each of us of what we have to change in our community and the world.

My rage has finally slowed down and fuels my work, holding space for any woman who has been hurt by izzat or honour.

Love, Roohan di rishtedari

$M K M$

\section{Process of Witnessing Our Collective Story of Resistance and Reclamation}

The second letter in this paper is a collective writing effort with Punjabi women who participated in my doctoral research. I will start by sharing the process of writing collectively, as it shaped the research process and the action research methods that I took in my research on HBV. The collective letter is a powerful way to express the grief, trauma, loss, and reclamation that the women and I experienced with our families and communities: transcending any one voice or one story, it combines the voices and stories of many women who have experienced exile and violence from izzat.

Between 2010 and 2015, I connected with six second-generation Punjabi women, who had survived HBV after transgressing the boundaries of izzat when they chose to be in an intimate partner relationship across race, culture, or caste boundaries, or with a same-sex partner. Each woman was exiled from her family or community after "coming out" about her intimate relationship. In ongoing in-depth life-history interviews with each woman, interviewees shared stories from early childhood to the present day, with a particular focus on how themes of izzat or 
honour featured throughout their lives, leading up to the moment when they were driven from their families or communities. I termed this moment the "impossible choice", where each woman confronted an ultimatum of either giving up her intimate relationship or being expelled from her family or community; their stories are documented in my doctoral dissertation (Mucina, 2015). In the last part of this paper, I share a collective open letter I wrote with some of the women, whom I will call sisters for the remainder of the paper. I use the term "sister" to describe a relationship that speaks to a shared experience beyond the parameters of the research. As an insider to this community and to this particular phenomenon, I would often share my own story with the women in the group in order to make a connection to their story and izzat. The work of Indigenous scholar Linda Tuhiwai Smith (1999) informs the insider approach I took, as she spoke about the negotiation that is required of an insider/outsider voice in research:

The critical issue with insider research is the constant need for reflexivity. At a general level, insider researchers have to have ways of thinking critically about their processes, their relationships and the quality and richness of their data and analysis. So too do outsiders, but the major difference is that insiders have to live with the consequences of their processes on a day-to-day basis for ever more, and so do their families and communities (Smith, 1999, p. 137).

As an insider I felt, as Smith suggested, a significant level of responsibility with every word I wrote in my dissertation. What my sisters and I created in the action part of the research represented a part of our lives that was raw and made us acutely vulnerable. This writing also challenged our communities to reflect in a public way on the impact of a cultural construct - izzat — and how patriarchy shapes our cultures. As an insider to this research, I live with the consequences of this letter every day, whether they are good or bad.

After the research process had begun, three of the six women agreed to participate in a circle with other women to consider some form of action around those HBV discourses with assimilationist agendas that portray our families and communities as "barbaric". The intention of the circle was to create a space where we could talk about how to move our stories towards action and to speak back to our own communities. We collectively chose to use our stories as a launching point for potential action and engagement about the impact of izzat on our lives and potentially on the lives of other second-generation Punjabi women. Each of us had come from an activist social justice background, so we were aware of the dynamics of sharing and the potential for collective work. However, this was the first time we were using our stories as the starting place for action. We revisited this challenge at various points throughout the process and gained insights on how difficult action and activism is for survivors or "insiders", recognizing the complex pain, trauma, and grief we must visit upon ourselves as we consider the larger context and how it shapes our individual stories.

The following questions directed our brainstorming sessions: "What messages would have been important for us to hear as young women going through those traumatic moments of being 
exiled from our families and/or communities?", "What message do we want to convey to our families? To our community?", and "What needs to change?" We also considered speaking directly to dominant media discourses; however, this endeavour felt futile at the time, as we sensed the media could use our stories to support racist or culturally prejudiced sentiments about our family and community, a risk we were not willing to take.

This work was not easy for any of us. There were many internal struggles along the way, and each woman took a break from the group at various times. The grief, loss, and trauma of displacement from our family and communities is a painful burden we carry with us almost every day, one that feels heavier when we are reminded of our loss. We collectively agreed that this action was not about making our individual stories into survival stories, which would give readers an excuse to see our stories as exceptions while maintaining the narrative that South Asian Canadian women in general require saving from their family and culture. The letter was intended to speak to the Punjabi and South Asian Canadian communities about the way that the boundaries placed on women as we perform and represent the izzat of the family are hurting us, displacing sisters and daughters, and leaving our families to live in unnecessary shame and guilt.

After meeting, eating, and drinking a lot of chai (tea) for two years, we finally agreed to spend an entire day together to write an open letter. I had written the shell of the letter after transcribing all of the recordings from our meetings and collecting the overarching themes we all identified as being important. I asked the women to contribute their changes through the web-based Google Docs service, which allows a shared document to be edited by anyone who has been given permission.

At this stage of the writing process, each of the women expressed the heaviness of reading and writing this letter, as it brought with it personal triggers. It was a painful undertaking to edit such a personal letter with multiple layers of meaning for each of us. One of my sisters eloquently articulated the difficulty in an email exchange to the group: "You wrote a beautiful letter and it hit me right in places where I realized that I still needed to work on strengthening for myself." After reflecting on these barriers, I asked if we could spend a full day together and go through the letter word for word, sentence by sentence, and write the final draft collectively. This seemed to work for everyone, and spoke to the importance of collective engagement on interpersonal connections when witnessing stories of trauma and pain.

When the day arrived, one of our sisters was unable to participate; she described having trouble getting out of bed when thinking about our collective project. I realized the process of speaking back to our past experiences and relationships is a harrowing task: to make meaning of the past brings up many internal struggles, while one must also live and breathe through the everyday struggles of daily life. As we pondered each word strung together in the letter, we were conscious of the heaviness in the room and took many collective breaks, gave each other hugs, and shared in food and, of course, chai. At the end of the full day, we had written a beautiful piece. We sent it to our sister who was unable to participate so she too could make changes. 
International Journal of Child, Youth and Family Studies (2021) 12(1): 13-30

The women were not willing to be the representation of this piece to the world, or have their stories demonstrated in any big public way. Each of them was very private, and it took tremendous strength for them to share their stories with me. They were satisfied with taking our action as far as the creation of this letter, and gave me permission to use this letter for future public knowledge mobilization in the form of publication or potentially a podcast. In a group email exchange one of the sisters spoke to what she called the "silence" — hesitation to represent this letter — referencing the spirit of the work we did: "This work is painful, so it makes sense that there is silence although challenging for the dissertation writer - it frustrates me when other folks are doing work that doesn't involve spirit and emotion ...".

Before I began this research, it was unclear to me what might happen when a group of women who are survivors of izzat-related violence or HBV come together to create something personal and political. This collective letter was a necessary part of our individual journeys and stories; we are witnessed by many others when it is read in public. Yet how we witnessed each other in our small group was as powerful as any public form of engagement possible with this work. The process we went through together will remain the most personal and powerful part of this research journey, and I am thankful to have been a part of this circle of sisterhood. I ask you, the reader, to see yourself as sitting outside a circle of strong, resilient, generous South Asian Canadian women as you read this last letter. This letter is addressed to our families and communities, so it is personal, yet speaks to the complex ways second-generation women and girls must navigate identity development, race, culture, and patriarchies inside and outside the family home. Ultimately, this letter is for the Punjabi and other South Asian communities in the diaspora - our fathers, brothers, and uncles; our mothers, grandmothers, and aunties; and, most importantly, our sisters who have moved through experiences of HBV in their lives. We hope you find meaning in what we are calling you all in to witness.

\section{A Letter of Love and Reclamation}

Dear Family,

This is an open letter to our families.

It is a letter to our individual families, our mothers, brothers, fathers, grandparents, aunts, uncles, cousins, those faces who said hello phuth (hello dear) to us every week at the gurudwara, temple, masjid.

To the aunties and uncles who made us dinner while our parents were working long hours.

To our nieces, nephews and little cousins who look up to us as their big sisters. To our children, and to our children yet to come. And finally to our future generations.

This is a letter for our fellow Punjabi sisters who may hear our words and struggle with these conversations with their own families. 
International Journal of Child, Youth and Family Studies (2021) 12(1): 13-30

This is a letter to the families that feel the distance from their daughters but cannot comprehend why we see the world differently.

This is for families who are hurting because they feel we, your daughters, are abandoning the family izzat and betraying your trust.

Families that believe they are protecting their daughters, yet don't realize this protection feels like control. Control over how bodies are read and who has access to them.

We are writing to call for a moment of silence and invite you to hear us.

Who are we, you ask?

We are women who have survived/experienced displacement and have been wounded by our families' words and actions. We have come together to speak in a collective voice to our family. To your family.

To you.

We are here to speak in a collective voice about the imposition of izzat in our lives. But most importantly, we are speaking so you can bear witness to our struggle, and we can come to a place of mutual respect and reciprocity.

We are speaking about our pain so that for a moment we can sit together with these words between us, in all our rawness and see/hear each other, actually see/hear each other. So you can for a moment hear/feel what we have to say.

Yet, we are not here to share our personal stories of trauma and tragedy. The details don't matter. The details that we have so often lingered over. In fact you know the details that shattered our sacred bonds, the relationship that we had before that moment of revelation. The day we came out of our closet of secrets. That day is the first day of our displacement from each of you, the day we were excommunicated from a world we called home. That day when our relationships died and new relationships grew from the ashes of the familiar. Relationships which will forever be filled with a shadow, a memory of pain, anger and words stir tears in each of us each time we remember them.

We see the tears in your eyes, even though they are dry, we feel the pain you sometimes hide and other times refuse to hide even though we beg you to stop.

But we are not here to speak about what happened on that day ... moment ... time when our worlds collided and you saw us with new eyes. The day you saw shame in our bodies and were convinced we had shattered your izzat ... the izzat of the family in the eyes of our community. When we chose to share our bodies with those you deem unsuitable. Other bodies that represent shame. That day we became outcasts. That day we feared what your eyes suggested. Where you were willing to go for your honour. 
International Journal of Child, Youth and Family Studies (2021) 12(1): 13-30

We write what we have thought of sharing with you numerous times. Words we have repeated in our heads but were too afraid to say aloud.

Afraid no one would listen. That you would not listen.

There are those who can take our words to fuel their fires of hatred of our foreign bodies and foreign ways. You warned me of these enemies of our culture many times, and we understand the risks we are taking by speaking out about izzat, honour, pain, but we must speak! We take this risk in the hopes you will be our foremost audience.

We speak and write here not so you can feel shame or even understand why we do what we do, why we choose this life, this partner, this solitary existence. We want you to come with us for a moment to remember our collective bond.

You have taught us the actions of a member of a clan reflect on everyone in the tribe. This is the collective bond we value, and it is from this worldview you chose to excommunicate my body.

Yet, in the spirit of this collectivism we ask you to listen with this teaching in mind.

We are here because of you.

And you are a part of us, as we are a part of you.

Therefore, your actions impact my body as much as my actions reflect your izzat.

Let us sit in this reciprocity and come to terms with our actions.

It is important to go back to the beginning.

You may wonder when we turned into daughters you couldn't recognize. But we have been carrying the pain and work of creating multiple worlds we live in, without your knowledge. We worked hard to lie. So hard that sometimes those lies became truths and we couldn't distinguish between the lines of reality and the world of lies we were creating around us. Covering tattoos, and hiding partners, masking love, this was our burden. But when our worlds collided and for a moment we could not bear to lie any more, we were asked to erase this world and continue with the mask of lies we had built for you to believe.

You demand us to forget, to move on, to not speak of this relationship ever again. This sacrifice was expected because this is what we are supposed to do as women. Sacrifice in the name of our family. The moment of resistance when we said nahin (no), was scary. Do you understand how difficult this choice was? Do you understand to make this choice meant loss? Tremendous loss either way. The day you said we must choose between family and \{them, her... him... myself\} we 
were condemned to an impossible place. A place of loss and trauma. And when we did choose the path away from you, family, your rejection of my body followed.

Maan, ammi, biji, bebe (mother)... you are usually the first to have a window into my world of resistance. It is with you I am most vulnerable, and where my need for acceptance is greatest. To be denied your love is a violence I cannot bear. That moment when I was afraid you were going to deny me was a moment I could not comprehend. I need your acceptance and love, and feel I deserve it. I know you deserve so much more from me, but I don't know what else to do. I hope you will always forgive. Ma you saw my worlds and as much as they haunt you and you fear my future, know you remain the constant I always come back to.

The pain of rejection is a wound so easily opened. It is trauma we carry with us in our everyday life, and will forever haunt us in our relationships. A shadow hanging over every relation. A threat that anyone who loves us can reject us at a moment's time. The loss that comes from this choice is like losing a womb sibling. Losing people who we have felt even before birth. And then the loss turns to a rebirth. There are many who have carried on with us. There are those who could not let go and despite the pain and sorrow, you still chose to communicate.

And many of you choose to remain in the ashes. Is it possible we can come to a rebirth with you? Or will we forever be dead to each other?

With some of you, there is a rebirth, with others there are still lies and the rest may still continue to reject our bodies and whom we chose to share our bodies with. Yet, there still continues to be an erasure of this world we shared with you, an erasure of our lovers who represent our transgressions. But do you know those same lovers crave your love? Do you know they have conversations with you when you are not there? Did you know these same lovers who you have erased have not erased you? Yet your conditions for contact with us are based on this erasure. You have created a world involving just us, without our love, our children, and our political struggle. Our world seems to be too scary for you to embrace, so it does not exist for you. This erasure is easy for us to fall into; we participate in erasing our partners when you need us to. But do you realize, for us to be truly present with each other we may need to address these erased bodies? We want you to come to a place where we can stand together and say to the world:

Yes this is who we are and only join our movement if you are happy to share in our truth.

But then again we may not be interested in having you recognize our world, not because we are scared but because when you acknowledge this world there is always so much pain. Avoidance has become a constant companion in our lives.

So you believe you did nothing wrong to lead us down this road. We reel in guilt, while you sit there in the power of knowing heteropatriarchy is on your side. You left us with no home, no place 
International Journal of Child, Youth and Family Studies (2021) 12(1): 13-30

to run to when we need help. Our only home is in the acceptance of our mother, and for that we are relieved.

We are trying to move on and hope you will search for us with love, before one of us carries on beyond this world. We will always leave a door open for you to call us back home.

To those families who find themselves struggling with their daughters transgressions, move beyond what you believe society, community, honour is telling you to do. Think with your heart and see the child you held on your laps, arms, or held hands with, see this daughter/sister is a part of you and whatever actions you expect of her body for your izzat, is coming from a place of power and control, not from a place of safety, security or even love. This daughter is transgressing because this is how she is surviving and defining herself in this racist, colonial, heteropatriarchal world.

She is surviving.

To those sisters who are finding their selves struggling to share these words with their families, remember why you are transgressing. You are not a bad brown girl or daughter. Your desire to not participate in the "good brown girl" ways is justified, because this image of the "good brown girl" was created to never be fulfilled, it is an image you are meant to fail.

Sister you are not alone, yet the road is lonely and scary, but the road is scattered with many of us who have chosen to carry on. We are here, come find us.

For the reader who has come on this journey, I leave you with these questions: What have you witnessed in this special issue? How will these stories, practices, and lessons shape your responses to gender-based violence, honour-based violence, and stories of survivance and resistance? How will this move you to action? 
International Journal of Child, Youth and Family Studies (2021) 12(1): 13-30

\section{References}

Abu-Lughod, L. (2002). Do Muslim women really need saving? Anthropological reflections on cultural relativism and its others. American Anthropologist, 104(3), 783-790. doi:10.1525/aa.2002.104.3.783

An-Na'im, A. (2000). Forced marriage. The Centre of Islamic and Middle Eastern Laws (CIMEL) \& The International Centre for the Legal Protection of Human Rights (INTERIGHTS) Honour Crimes Project. http://www.soas.ac.uk/honourcrimes/resources/file55689.pdf?filename=Forced+Marriage

Burstow, B. (2003). Toward a radical understanding of trauma and trauma work. Violence Against Women, 9(11), 1293-1317. doi:10.1177/1077801203255555

Brydon-Miller, M., Greenwood, D., \& Maguire, P. (2003). Why action research? Action Research, 1(1), 9-28. doi:10.1177/14767503030011002

CBC Fifth Estate. (2012, February 10). The House of Shafia. https://www.cbc.ca/fifth/m episodes/2011-2012/the-house-of-shafia

CBC Fifth Estate. (2019, February 17). Justice for Jassi Sidhu? https://www.cbc.ca/fifth/episodes/2018-2019/justice-for-jassi-sidhu

Espiritu, Y. L. (2001). We don't sleep around like white girls do: Family culture, and gender in Filipina American lives. Signs, 26(2), 415-440. doi:10.1086/495599

Farmer, P. (2003). Pathologies of power: Health, human rights, and the new war on the poor. University of California Press.

Freire, P. (1973). Pedagogy of the oppressed. Seabury.

Haque, E. (2010). Homegrown, Muslim and other: Tolerance, secularism and the limits of multiculturalism. Social Identities: Journal for the Study of Race, Nation and Culture, 16(1), 79-101. doi:10.1080/13504630903465902

Herman, J. L. (1992). Trauma and recovery. Basic Books.

Holder, J. (2015). Our community action research project: A blueprint for resistance. In S. Strega \& L. Brown (Eds.) Research As resistance: Revisiting critical, indigenous, and antioppressive approaches (2nd edition; Ch. 4). Canadian Scholars' Press, Women's Press.

Laub, D. (1995). Truth and testimony: The process and the struggles. In C. Caruth (Ed.), Trauma: Exploration in memory (pp. 61-75). Johns Hopkins University Press.

Mucina, M. K. (2015). Transgressing boundaries of izzat: Voices of second-generation Punjabi women surviving and transgressing "honour" related violence in Canada [Doctoral dissertation, University of Toronto, OISE]. Tspace. https://tspace.library.utoronto.ca/handle/1807/69458 
International Journal of Child, Youth and Family Studies (2021) 12(1): 13-30

Mucina, M. K. (2018). Exploring the role of "honour" in son preference and daughter deficit within the Punjabi diaspora in Canada. Canadian Journal of Development Studies, 39(3), 426-442. doi:10.1080/02255189.2018.1450736

Pain, R. (2004). Social geography: Participatory research. Progress in Human Geography, 28(5), 652-663. doi:10.1191/0309132504ph511pr

Rajiva, M. (2005). Bridging the generation gap: Exploring the differences between immigrant parents and their Canadian-born children. Canadian Issues, Spring, 25-28. Retrieved from https://search.proquest.com/openview/af82808eb4b45d8b6b6bc709fd50f619/1?pq$\underline{\text { origsite }}=$ gscholar\&cbl $=43874$

Razack, S. (2003). A violent culture or culturalized violence? Feminist narratives of sexual violence against South Asian women. Studies in Practical Philosophy, 3(1), 80-104. doi:10.5840/STUDPRACPHIL2003317

Razack, S. H. (2004). Imperiled Muslim women, dangerous Muslim men, and civilized Europeans: Legal and social responses to forced marriages. Feminist Legal Studies, 12, 129174. doi:10.1023/B:FEST.0000043305.66172.92

Saywell, S. (Director). (2010). In the name of family [Documentary film]. Bishari Films.

Smith, L. T. (1999). Decolonizing methodologies: Research and Indigenous people. Zed Books.

Statistics Canada. 2011. Generation status: Canadian-born children of immigrants [Catalogue no. 99-010-X2011003]. Ottawa. https://www12.statcan.gc.ca/nhs-enm/2011/as-sa/99-010-x/99010-x2011003_2-eng.pdf

'Suicidal' Shafia daughter described by school official. (2011, November 23). CBC News. https://www.cbc.ca/news/canada/montreal/suicidal-shafia-daughter-described-by-schoolofficial-1.1036382? cmp $=$ rsS

Tripp, R. (2013). Without honour: The true story of the Shafia family. HarperCollins Canada.

Tuck, E. (2009). Suspending damage: A letter to communities. Harvard Educational Review, 79(3), 409-427. doi:10.17763/HAER.79.3.N0016675661T3N15

Vizenor, G. (2013). Resistance in the blood. In E. Tuck, \& K. W. Yang (Eds.), Youth resistance research and theories of change. Routledge. doi:10.4324/9780203585078

van der Muelen, E. (2011). Action research with sex workers: Dismantling barriers and building bridges. Action Research, 9(4), 370-384. doi:10.1177/1476750311409767

Walton-Roberts, M., \& Pratt, G. (2006). Mobile modernities: A South Asian family negotiates immigration, gender and class in Canada. Gender, Place and Culture: A Journal of Feminist Geography, 12(2), 173-195. doi:10.1080/09663690500094823 